\title{
Evaluation of Methods of Peak Runoff Determination using Catchment Characteristics for Jere Sub-basin, Gurara River Basin, North Central Nigeria
}

\author{
A.W. Salamia, R.B. Mudashiru*, b and S.O. Bilewuc \\ aDepartment of Water Resources and Environmental Engineering, University of Ilorin, Ilorin, Nigeria. \\ bDepartment of Civil Engineering, Federal Polytechnic Offa, Offa, Nigeria. \\ cDepartment of Water Resources and Environmental Engineering, University of Ilorin, Ilorin, Nigeria
}

Received 28 January 2016; Accepted 2 February 2017

\begin{abstract}
This paper presents the evaluation of methods of determination of peak runoff for an ungauged catchment. The present study made use of Geographical Information System (GIS) for the morphometric analysis of four sub-catchments within Jere sub-basin in Gurara Basin, Nigeria. Various morphometric parameters were computed and analyzed as sub-basin characteristics are important factors in determining the runoff. Three methods of peak runoff estimation were used to determine peak runoff of the study area for four return periods. The results of the peak runoff estimation based on rational method for the four sub-catchments for 25-year, 50-year, 75-year and 100-year return periods varied between $224 \mathrm{~m}^{3} / \mathrm{s}$ and $1036 \mathrm{~m}^{3} / \mathrm{s}$, while the results for the SCS method varied between $105.3 \mathrm{~m}^{3} / \mathrm{s}$ and $162.05 \mathrm{~m}^{3} / \mathrm{s}$ and the results from the Cypress Creek method varied between $22.8 \mathrm{~m}^{3} / \mathrm{s}$ and $86.55 \mathrm{~m}^{3} / \mathrm{s}$. The results obtained from the three methods showed that there are significant differences in the peak runoff results and also there are significant differences in the peak runoff results for the different return periods.
\end{abstract}

Keywords: Digital elevation model; Geographic information system; Morphometric parameters; Return periods; Runoff; Sub-basin; Sub-catchment.

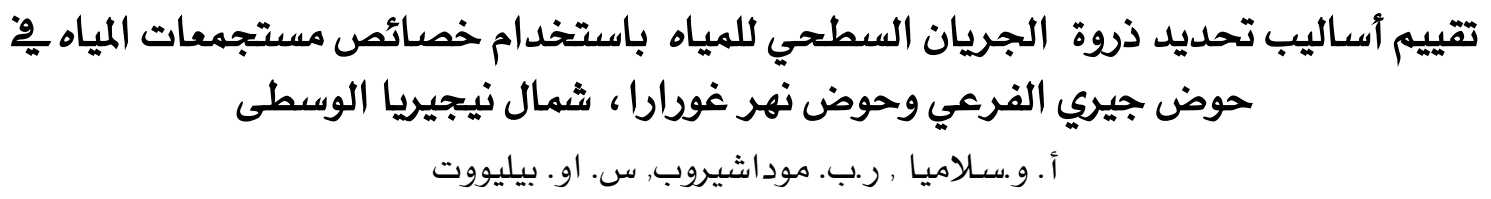

الملخص: تقدم هذه الورقة البحثية تقييم لطرق تحديد ذروة الجريان السطحي للمياه وِّ مستجمعات المياه غير المقفلة. قامت هذه الدراسة باستخدام نظام المعلومات الجفرابِ (جي اي اس) لتحليل قياسـات الشكل الخارجي و التضاريس (مورفومتري) لأربعة مستجمعات فرعية داخل حوض جيري الفرعي يٌ حوض غورارا بنيجيريا. وتم احتساب وتحليل العديد من العوامل المورفومترية كخصائص للحوض الفرعي باعتبارها عوامل مهمة پِّ تحديد الجريان السطحي. قام البحث باستخدام ثلاث طرق لتحديد ذروة الجريان السطحي بهنطقة الدراسة لأربع فترات عودة. وتراوحت نتائج تقدير ذروة الجريان السطحي

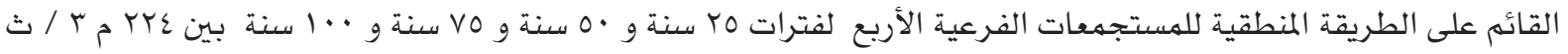

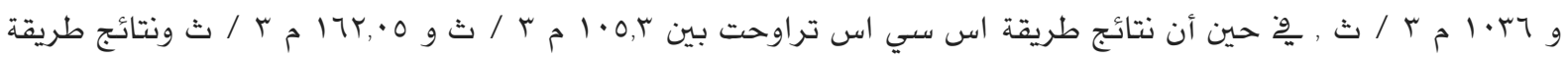

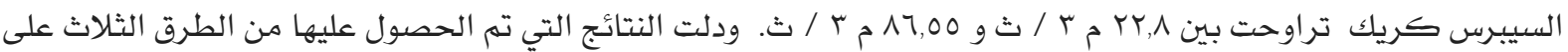
وجود فروق جوهرية يِّ نتائج ذروة الجريان السطحي للطرق المستخدمة وِّ المستجهعات الفرعية الأربع بهنطقة الدراسة وأيضا على وجود فروق ذات دلالة إحصائية وِّ نتائج ذروة الجريان السطحي لفترات العودة المختلفة.

الكلمات المفتاحية : نهوذج الارتقاء الرقهي، نظام المعلومات الجفراوِ، معاملات الشكل الخارجي و التضاريس (المورفومترية)، فترات العودة، الجريان السطحي، الحوض الفرعي، المستجمع الفرعي.

*Corresponding author's e-mail: bunmbello@gmail.com 


\section{Introduction}

In Nigeria and the world generally, peak flows determine the design specifications of structures such as embankments, channels, bridges and dams. Peak flows also determine the capacity of the control sections of flow-through measurement systems and the collection pipes and transfer conduits of volumetric collection vessels. Some estimate of peak flows must be made before the design of these systems can be completed (Miller 1994). Design peak flows are linked to particular return periods, such as the maximum flow in 5, 10, 25, etc., years and design specifications are a balance between economic cost and the prevention of failure of the structure (Miller 1994). Jere is a sub-basin of Gurara River basin where the Federal Ministry of Agriculture and Water Resources (FMA and WR) in Nigeria is constructing a dam for the purpose of inter basin water transfer to supplement the lower Usama and Shiroro reservoirs for municipal water supply and hydroelectric power generation, respectively (FMAWR 1986) Ibrahim and Isiguzo 2009). The relevance of determining the peak runoff for the basin cannot be overemphasized as past events that showed Gurara River had flooded at one time or another. In 1998 and 1999, Gurara River flooded above the capacity of its channel taking over farm lands and houses in Kutamgba, a village, at the same time when heavy rains pressured the Kainji, Jebba and Shiroro dams located in the same middle belt region of Nigeria with Gurara River.

Catchment characteristics add a lot to runoff volume. Generally, the basin size is the most important basin characteristic in determining the quantity and timing of surface runoff at the outlet. The larger the basin size, the greater potential amount of rainfall that can be captured and routed to the basin outlet. Basin size primarily controls the volume of runoff past the outlet. Basin shape and topography are key basin characteristics controlling the routing of runoff to the basin outlet, and primarily control the timing of the peak, and to a lesser extent, the magnitude of the peak flow. Soil properties determine, to a large degree, the infiltration rate, storage, and release of the precipitation from the overburden. Soils affect the amount and type of vegetation, which also influence the infiltration rate. Land use and modifications to the natural surface by practices such as deforestation, mining, and farming, as well as structures such as dams, levees, bridges, channels, and pavement also can have a significant effect (Carluer et al. 2004). In the present study, the basin characteristics were determined using ARC GIS, historical rainfall data, rainfall intensity and the Curve number used was based on soil characteristics and land use details of watershed.

Many hydrologic methods are available for estimating peak flows from a basin, and no single method is applicable to all basins (Donald and Richard, 2005). Estimating the volume of runoff or the peak runoff rate is expected to occur from a specific watershed in response to a specific rainfall event is a very difficult challenge. Hydrologists have struggled to define the many critical relationships that define the processes and the interrelationships between these processes for years. One of the first successful attempts to quantify a watershed's runoff response was developed by the USDASCS (1972) when they published what we know today as the SCS or Soil-Cover-Complex Method. A second early method was known as the Rational Method. The Soil-Cover-Complex Method was originally developed to calculate the volume of runoff only. In recent years, this method has been further developed to yield the peak rate of runoff as well. The Rational Method is a simple equation that is only able to estimate the peak runoff rate. The Rational Method which estimates peak flows is a simplified representation of the complicated process whereby rainfall amount and intensity, catchment conditions and size as well as human activity, determine runoff amount, but it is suitable where the consequences of the failure of structures are limited.

A great deal of research has been undertaken to develop hydrological models that can predict runoff peak flows and volumes. The majority, however, are not suited to general use. Sometimes they are too complex, but most frequently they are limited by the geographical localities and hydrological conditions within which the data were collected. Many models are regression models and their value is difficult to assess outside their own particular circumstances (Miller 1994).

Presented here are three methods that can be used to predict peak flows and three models that are suitable to estimate runoff volumes. They are suitable for use with a wide range of catchment sizes and conditions. These methods of estimation have certain drawbacks: they can be relatively inaccurate because they make simplifying assumptions; and they require the 
availability of some primary data such as catchment physical characteristics and rainfall. However, they have been used for some time in a variety of environments with success and are based on measurements from a great number of catchments, with a wide range of physical characteristics.

\section{Materials and Methods}

\subsection{Description of the Study Area}

The Jere is a sub-basin in the Gurara basin, which lies between $9^{\circ} 28^{\prime}-9^{\circ} 44^{\prime} \mathrm{N}$ and longitudes $7^{\circ} 18^{\prime}-7^{\circ} 32^{\prime} \mathrm{E}$ covering a total area of about $483 \mathrm{~km}^{2}$, with basin length of $354.74 \mathrm{~km}$ and average slope of 0.0004 (as determined in this study using GIS); it consists of four subcatchments and has three stream orders as shown in Table 1. Figure 2 shows the Jere subbasin and the stream order in the sub-basin. Jere sub-basin falls in Kargarko local government area of Kaduna State in Nigeria. It has an area of $1864 \mathrm{~km}^{2}$ and a population of 240,943 at 2006 census. It comprises about eleven districts which are Shadalafiya, Katugal, Kushe, Jere, Dogon Kurmi, Kenyi, Kurmin Dangana, Kubacha, Aribi and Kagarko districts. The people of Kagarko are predominantly Koro by tribe. The people in this region are mostly farmers. About $70 \%$ of ginger produced in Kaduna State comes from this local government area. Figure 1 shows the location of the study area in Gurara basin and in Nigeria.

\subsection{Data Collection and Analysis}

\subsubsection{Delineating of sub-basin}

The drainage network of Jere sub-basin was delineated using ESRI Software Arc GIS 10.3. The steps followed include; setting up work environment, creating a depressionless Digital Elevation Model, creating a flow direction grid, creating a flow accumulation grid, creating outlet point, creating pour points and then delineating the sub-basin. The parameters required for morphometric analysis are computed using ArcGIS software. Reflection Radiometer (ASTER) images were loaded onto Geographic Information Systems (GIS) environment. The remotely sensed data are geometrically rectified to digitize the pattern of sub-basin with the help of GIS software. The drainage patterns for the Jere sub-basin along with basin boundaries are digitized as a line feature giving a unique identity for each order of stream which was engendered from the DEM. The ArcGIS approach was used for drainage generation which is more coherent and reliable when compared to a manual approach. Based on the cumulative number of the upstream cells draining to each cell, flow accumulation, flow direction was defined. Also, a stream network in the watershed was defined. The watershed area was evaluated by calculating the geometry of the derived watershed polygons, and length of the watershed was calculated by summing the length of the main stream channel and the distance from the top of the main channel to the watershed boundary. By summing the lengths of all stream segments in each sub-watershed, the total stream length was calculated, by using Strahler's ordering system, a stream segment with no tributaries that flows from the stream source is denoted as a first-order segment. A second order segment is created by joining two first-order segments, a third-order segment by joining two second order segments, and so on. Jere sub-basin consists of four sub-catchments and has three stream orders as shown in Table 1. Table 2 shows the stream lengths of the subcatchments, Table 3 shows the linear properties of the sub-catchments and Table 4 shows the relief properties of the sub-catchments which were obtained from delineation and morphometric analysis of the sub-basin. Figure 2 shows the Jere sub-basin, the sub-catchments and the stream order in the sub-basin.

Also, the map showing the jere sub-basin slope, soil distribution and land use are presented in Figs. 3, 4, and 5 respectively.

\subsection{Estimating of Peak Runoff}

\subsubsection{Rational method}

The rational method of predicting a design peak runoff rate is expressed by the equation (Schwab et al. 1981).

$Q_{p}=0.0028 \mathrm{CiA}$

Where $C=$ the coefficient of runoff $(0-1)$. The soil in the sub-basin belongs mostly to the 


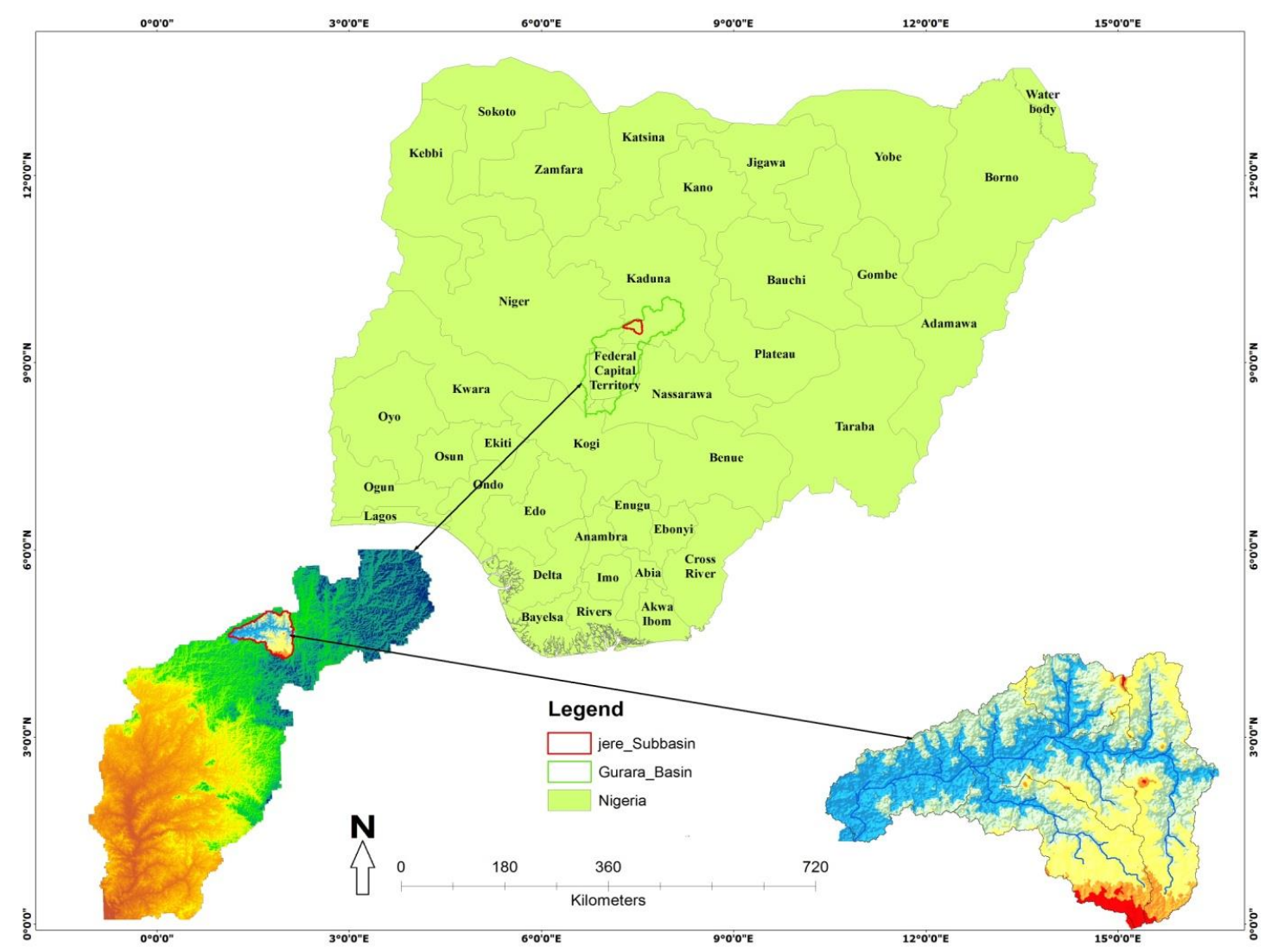

Figure 1: Location map of Nigeria showing Gurara basin and Jere sub-basin.

Table 1. Stream order of the sub-catchments within Jere sub-basin.

\begin{tabular}{c|c|c|c|c|c}
\hline \multirow{2}{*}{$\begin{array}{c}\text { River sub- } \\
\text { basin }\end{array}$} & Orders & \multicolumn{4}{|c}{ Sub catchments } \\
\cline { 3 - 6 } & & $\mathbf{1}$ & $\mathbf{2}$ & $\mathbf{3}$ & $\mathbf{4}$ \\
\hline \multirow{3}{*}{ Jere } & $1^{\text {st }}$ & 7 & 4 & 13 & 7 \\
& $2^{\text {nd }}$ & 2 & 1 & 4 & 1 \\
& $3^{\text {rd }}$ & 0 & 0 & 1 & 0 \\
& Total Stream & 9 & 5 & 18 & 8 \\
\hline
\end{tabular}

Table 2. Stream length of the sub-catchments within Jere sub-basin $(\mathrm{km})$.

\begin{tabular}{|c|c|c|c|c|c|c|c|c|}
\hline $\begin{array}{c}\text { Sub-catchment } \\
\text { ID } \\
\text { Order }\end{array}$ & 1 & 2 & 3 & 4 & $\begin{array}{c}\text { Total Stream } \\
\text { Length in } \\
\text { order }(\mathbf{k m})\end{array}$ & $\begin{array}{l}\text { Mean Stream } \\
\text { Length(km) }\end{array}$ & $\begin{array}{c}\text { Stream } \\
\text { length ratio }\end{array}$ & $\begin{array}{c}\text { Bifurcation } \\
\text { ratio }\end{array}$ \\
\hline $1^{\mathrm{ST}}$ & 16.36 & 10.17 & 22.58 & 16.8 & 66.31 & 2.3933 & 0.3864 & 3.875 \\
\hline $2^{\mathrm{ND}}$ & 5.18 & 3.04 & 13.2 & 4.20 & 25.62 & 2.6420 & 0.0722 & 8.000 \\
\hline $3^{\mathrm{RD}}$ & & & 1.85 & & 1.85 & 2.1128 & & \\
\hline $\begin{array}{l}\text { Total stream } \\
\text { Length in sub- } \\
\text { catchment }\end{array}$ & 21.54 & 13.21 & 38.03 & 21 & 93.78 & 2.6250 & & \\
\hline
\end{tabular}




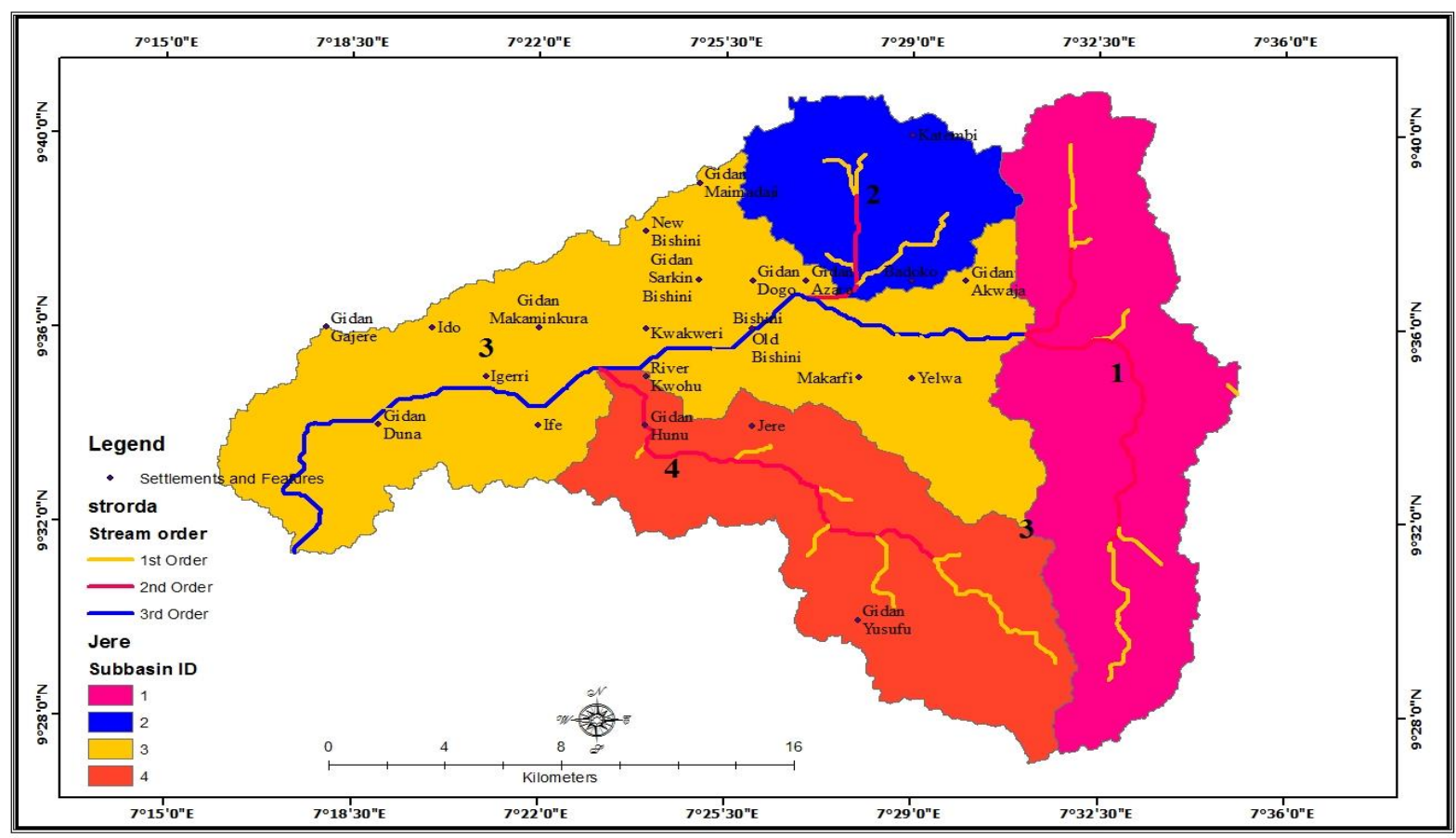

Figure 2. The Jere sub-basin showing the stream orders and the sub-catchments.

Table 3. Linear Properties of the sub-catchments within Jere sub-basin.

\begin{tabular}{cccccc}
\hline Sub-catchment ID & $\mathbf{1}$ & \multicolumn{2}{l}{$\mathbf{2}$} & $\mathbf{4}$ & Total \\
\hline Basin area $\left(\mathrm{km}^{2}\right)$ & 124.06 & 50.73 & 197.37 & 111.25 & 483.423 \\
Basin perimeter $(\mathrm{km})$ & 92.07 & 46.46 & 140.07 & 85.88 & 364.479 \\
Basin Length $(\mathrm{km})$ & 92.00 & 46.34 & 130.12 & 86.11 & 354.738 \\
\hline
\end{tabular}

Table 4. Relief properties of the sub-catchments within Jere sub-basin.

\begin{tabular}{ccccc}
\hline Sub-catchment ID & $\mathbf{1}$ & $\mathbf{2}$ & $\mathbf{3}$ & $\mathbf{4}$ \\
\hline Basin Relief $(\mathrm{km})$ & 0.31 & 0.31 & 0.31 & 0.31 \\
\hline Relief ratio (slope) & 0.003367 & 0.006690 & 0.002382 & 0.003600 \\
Ruggedness number & 0.05382 & 0.08072 & 0.059732 & 0.058517
\end{tabular}




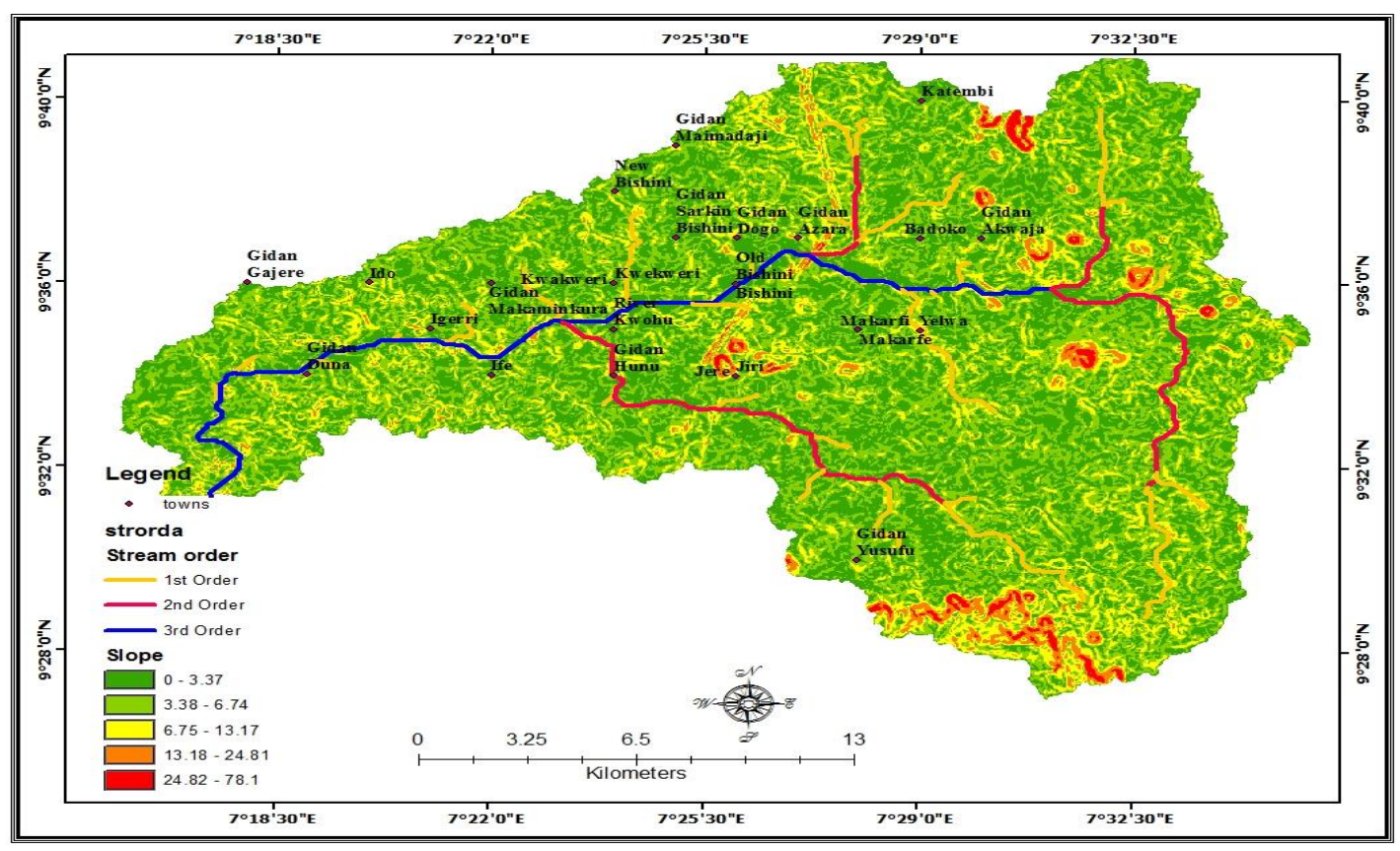

Figure 3. Slope of the Jere sub-basin.

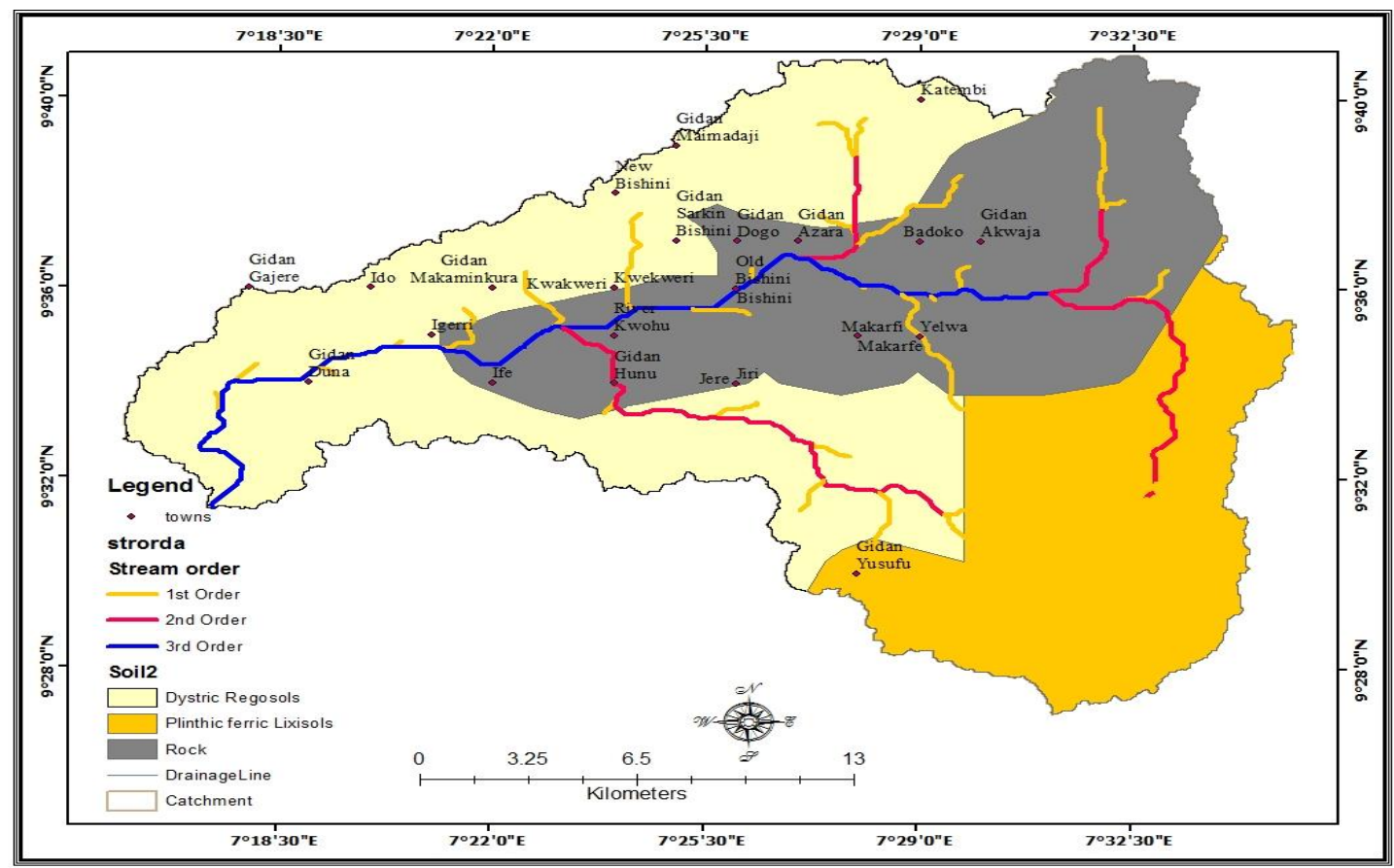

Figure 4. Soil distribution of the Jere sub-basin. 
dystric regosols as shown in Figure 3 belonging to base of soil resources which are weakly developed from mineral soil in unconsolidated material. Some regosols are used for capital intensive irrigated farming, but most common land use is low volume grazing. The soil type is particularly common in arid areas, in dry tropics and in mountain regions. Some parts of the Jere sub-basin contain Plinthic Ferric Lixisols which are strongly weathered soils from unconsolidated, strongly leached, finely textured materials from region of tropical warm temperate with pronounced dry season. They are often used for perennial crops or low volume grazing and these groups of soil are prone to erosion because of their unstable surface soil structure. For the purpose of this study, the coefficient of runoff of 0.20 would be used as the soil type and land use of the study area falls within ( Rural- Average infiltration rates- Cultivated pasture from the table of runoff coefficient for rational formula).
$A$ = the catchment area (ha)
$I=$ rainfall intensity $(\mathrm{mm} / \mathrm{h})$
$Q_{p}=$ peak runoff rate $\left(\mathrm{m}^{3} / \mathrm{s}\right)$

Note: $1 \mathrm{~km}^{2}=100 \mathrm{ha}$, the area for each subcatchment in Jere sub-basin were obtained from the DEM. The rainfall intensities for return periods of 25-years, 50-years, 75-years and 100years were obtained in (Mudashiru 2015) as $78.89 \mathrm{~mm} / \mathrm{h}, \quad 86.35 \mathrm{~mm} / \mathrm{h}, \quad 90.68 \mathrm{~mm} / \mathrm{h}$ and $93.75 \mathrm{~mm} / \mathrm{h}$ respectively.

The peak flow for various rainfall intensities were determined by adopting equation (1). The results are summarized in Tables 5 for the four sub-catchments within the Jere sub-basin.

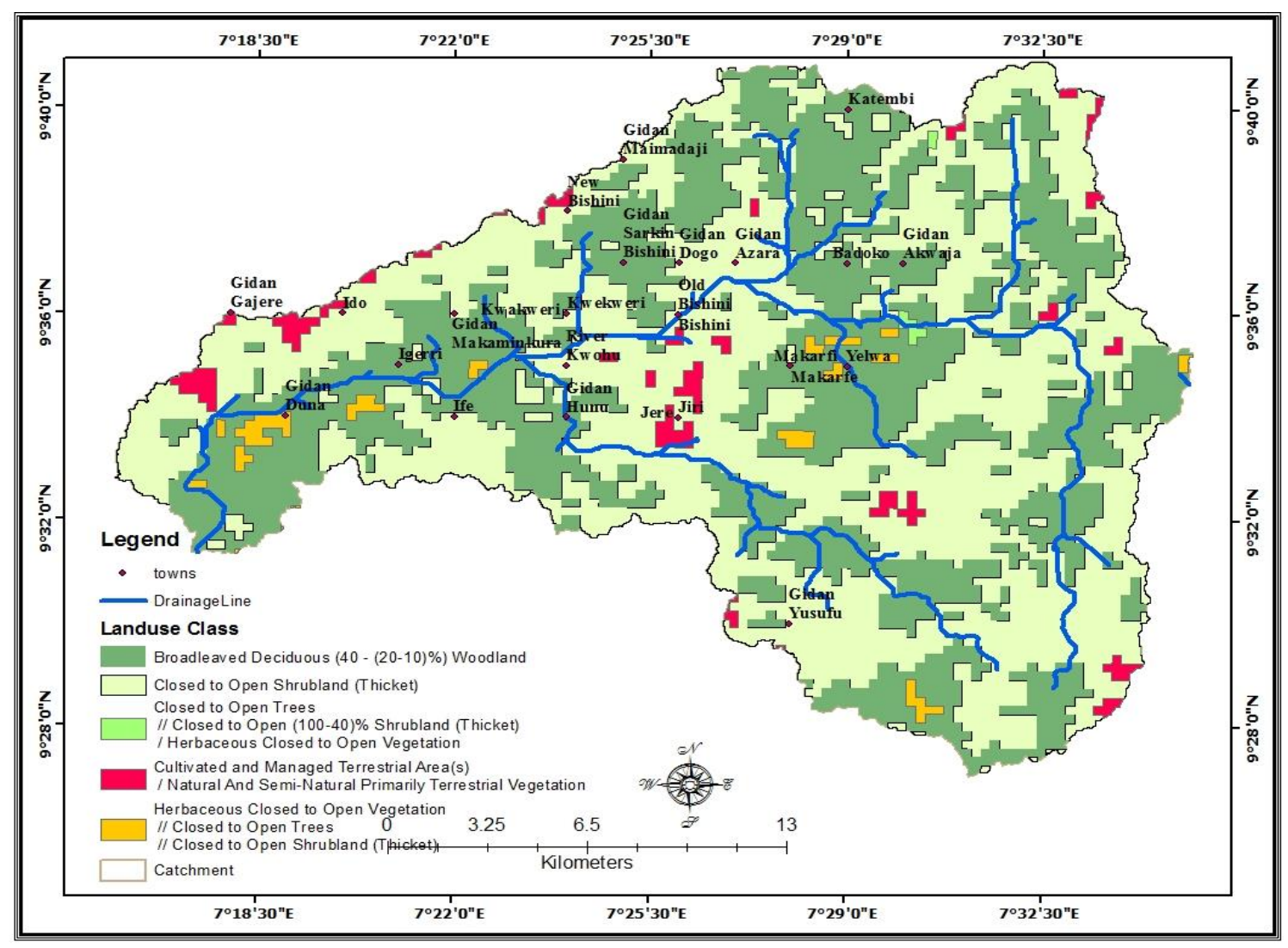

Figure 5. Land use map of the Jere sub-basin. 


\subsubsection{Soil conservation service (SCS) method}

The peak discharge, the time to peak and the lag time can be determined in accordance to (SCS 1972; Viessman et al. 1989; and Ogunlela and Kasali 2002).

\section{Peak discharge:}

The peak discharge can be obtained through the Eq. (2), (Ramirez 2002).

$\mathrm{q}_{\mathrm{p}}=\frac{2.08 \mathrm{~A}}{\mathrm{t}_{\mathrm{p}}}$

where,

$\mathrm{q}_{\mathrm{p}}=$ peak discharge $\left(\mathrm{m}^{3} / \mathrm{s} / \mathrm{cm}\right)$

$\mathrm{A}=$ watershed area $\left(\mathrm{km}^{2}\right)$

$t_{p}=$ time to peak $(h)$

\section{Time to peak and lag time:}

$t_{p}=\frac{t_{c}+0.133 t_{c}}{1.7}$

where;

$t_{c}=$ time of concentration (h)

$\mathrm{t}_{\mathrm{r}}=$ storm duration $(\mathrm{h})$

$t_{\mathrm{L}}=$ lag time $(\mathrm{h})$ $t_{c}=$ time of concentration (hr) (Kirpich's equation).

$t_{c}=0.06628\left\{\frac{L^{0.77}}{S^{0.385}}\right\}$

where;

$\mathrm{L}=$ length of channel (stream) in $\mathrm{km}$

$\mathrm{S}=$ Slope of channel $(\mathrm{m} / \mathrm{m})$

Equation 4 was adopted in the estimation of the time of concentration for each of the subcatchments. This was used to determine the values for both the peak discharge $\left(\mathrm{q}_{\mathrm{p}}\right)$ and time to peak ( $\left.t_{\mathrm{p}}\right)$ which was applied to the dimensionless hydrograph ratios to obtain points for the unit hydrograph using equations 2 and 3. The peak discharge, time to peak and lag time were determined in accordance to SCS (1972), Viessman et al. (1989) and Ogunlela and Kasali (2002). The parameters used for the analysis are as presented in Tables 3 and 4 . However, the parameters obtained such as catchment length $(\mathrm{L})$, time of concentration $\left(\mathrm{t}_{\mathrm{c}}\right)$, time to peak $\left(t_{p}\right)$, catchment slope $(S)$, peak discharge $\left(\mathrm{Q}_{\mathrm{p}}\right)$ and the catchment area $(\mathrm{A})$ are presented in Table 6.

The estimated values for both the peak discharge $\mathrm{q}_{\mathrm{p}}$ and time to peak $t_{\mathrm{p}}$ are applied to the dimensionless hydrograph ratios to obtain points for the unit hydrograph as presented in Figs. 6-9.

Table 5. Summarized peak runoff values using Rational method.

\begin{tabular}{ccccc}
\hline & \multicolumn{4}{c}{ Peak runoff Values (m $\left.\mathbf{m}^{3} / \mathbf{s}\right)$} \\
\cline { 2 - 5 } Recurrence Interval & Sub-catchment 1 & Sub-catchment 2 & Sub-catchment 3 & Sub-catchment 4 \\
\hline 25-Year & 548.08 & 224.12 & 871.95 & 491.48 \\
50 -Year & 599.90 & 245.31 & 954.40 & 537.96 \\
75 -Year & 629.99 & 257.61 & 1002.26 & 564.94 \\
100-Year & 651.32 & 266.33 & 1036.19 & 584.06 \\
\hline
\end{tabular}

Table 6. Parameters for the generation of unit hydrograph.

\begin{tabular}{ccccccc}
\hline $\begin{array}{c}\text { Sub- } \\
\text { catchment }\end{array}$ & $\mathbf{L}(\mathbf{k m})$ & $\mathbf{A}\left(\mathbf{k m}^{2}\right)$ & $\mathbf{S}_{\mathbf{c}}(\mathbf{s l o p e})$ & $\mathbf{t}_{\mathbf{c}}(\mathbf{h})$ & $\mathbf{t}_{\mathbf{p}}(\mathbf{h})$ & $\mathbf{Q}_{\mathbf{p}}(\mathbf{m} \mathbf{3} / \mathbf{s} / \mathbf{c m})$ \\
\hline 1 & 92.00 & 124.06 & 0.0034 & 19.25 & 2.6 & 20.48 \\
2 & 46.34 & 50.73 & 0.0067 & 8.74 & 5.72 & 18.44 \\
3 & 130.12 & 197.37 & 0.0024 & 28.74 & 18.81 & 21.82 \\
4 & 86.11 & 111.25 & 0.0030 & 19.19 & 12.56 & 18.42 \\
Total & 354.57 & 483.41 & 0.0155 & 75.92 & 39.69 & 79.16 \\
\hline
\end{tabular}




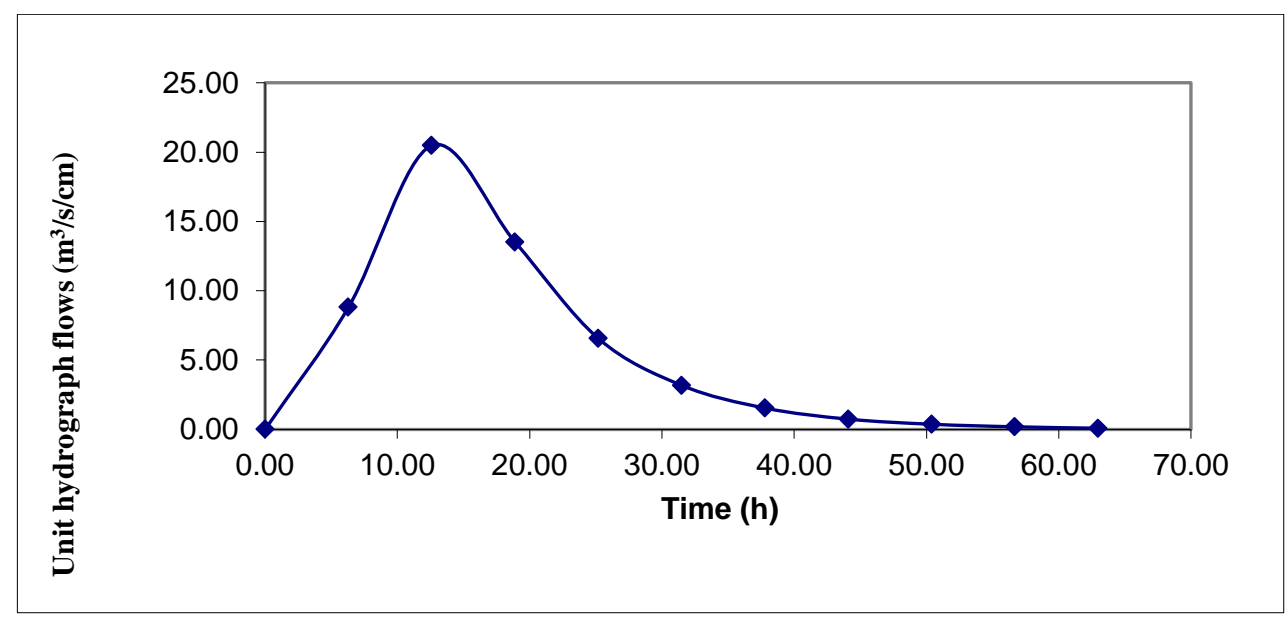

Figure 6. Unit hydrograph flows versus time for sub-catchment 1.

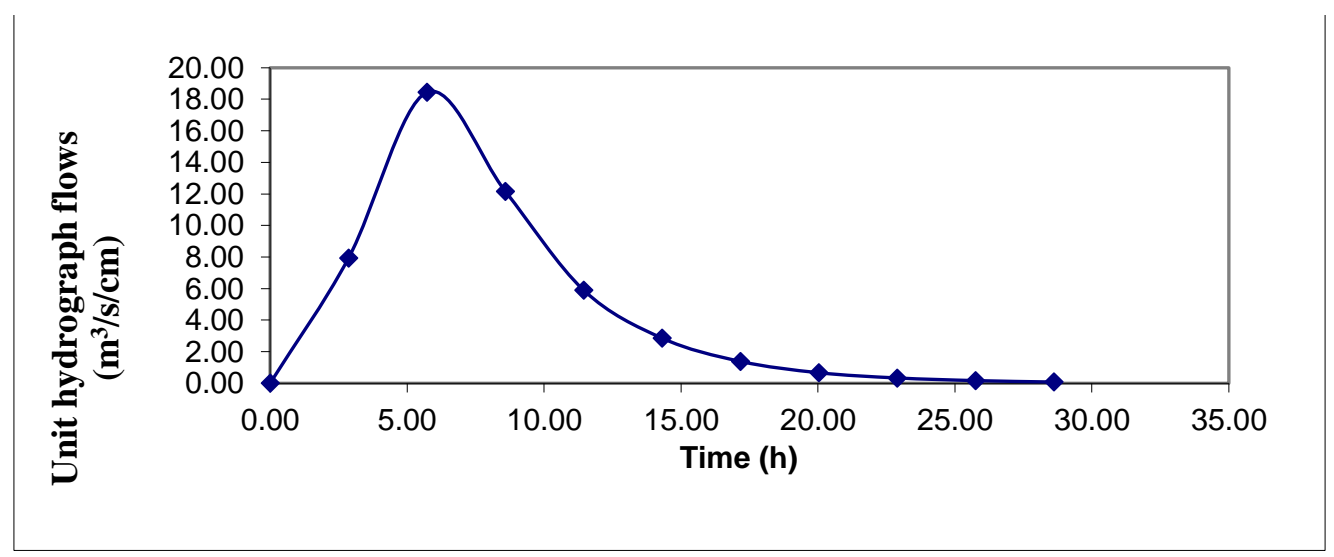

Figure 7. Unit hydrograph flows versus time for sub-catchment 2.

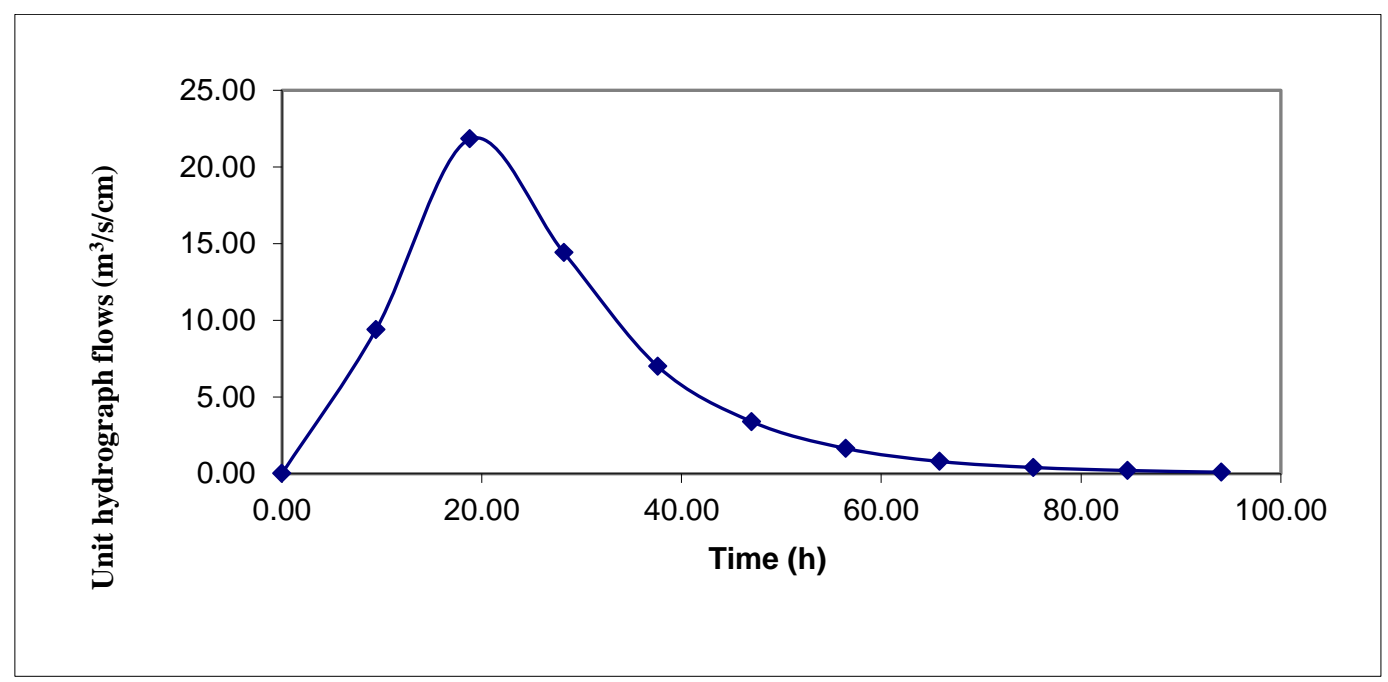

Figure 8. Unit hydrograph flows versus time for sub-catchment 3. 


\section{a) Estimation of design storm (runoff) hydrograph}

The estimated synthetic unit hydrograph from SCS method was used to develop the runoff hydrographs due to annual peak daily rainfall event over the sub-basin. The design runoff hydrographs for the selected rainfall of recurrence intervals of 25-years, 50-years, 75years and 100-years were developed through hydrograph convolution. Hydrograph convolution involves multiplying the unit hydrograph ordinates by incremental rainfall excess, adding and lagging in a sequence.

b) Determination of rainfall depth of different return periods.

The rainfall depth of 25-years, 50-years, 75years and 100 -years were $157.79 \mathrm{~mm}, 172.71 \mathrm{~mm}$, $181.38 \mathrm{~mm}$ and $187.51 \mathrm{~mm}$ respectively were determined according to (Mudashiru 2015).

\section{c) Estimation of Rainfall Excess}

In the SCS method, the excess rain volume, $\mathrm{Q}$, depends on the volume of precipitation, $\mathrm{P}$, and the volume of the total storage, $\mathrm{S}$, which includes both the initial abstraction, $\mathrm{I}_{\mathrm{a}}$, and the total infiltration $\mathrm{F}$. The relation between rainfall excess and total rainfall (on twenty-four hour basis) is then (McCuen and Bondelid 1983).

$Q=\frac{(P-0.2 S)^{2}}{(P+0.8 S)}$

$P=\frac{P^{*}}{24} * P_{T}$ where,

$\mathrm{P}=$ accumulated rainfall $(\mathrm{mm})$.

$P_{T}=$ rainfall recurrence interval of the sub-basin (mm).

$\mathrm{P}^{*}=$ precipitation ratio.

$\mathrm{P}^{*} / 24=$ precipitation ratio dimensionless value in SCS type II for estimation of rainfall excess.

$S=$ volume of total storage $(\mathrm{mm})$.

Note that equation (15) contains only one unknown, the storage parameter S. This parameter in $(\mathrm{mm})$ can be obtained from

$S=\frac{25400}{C N}-254$

where;

$\mathrm{CN}$ is runoff curve number

$\mathrm{CN}$ value of 75 was adopted based on the soil type which is particularly common in arid areas, in dry tropics and in mountain regions. Some parts of the Jere sub-basin contain Plinthic Ferric Lixisols which are strongly weathered soils from unconsolidated, strongly leached, finely textured materials from region of tropical warm temperate with pronounced dry season. They are often used for perennial crops or low volume grazing and these groups of soil are prone to erosion because of their unstable surface soil structure.

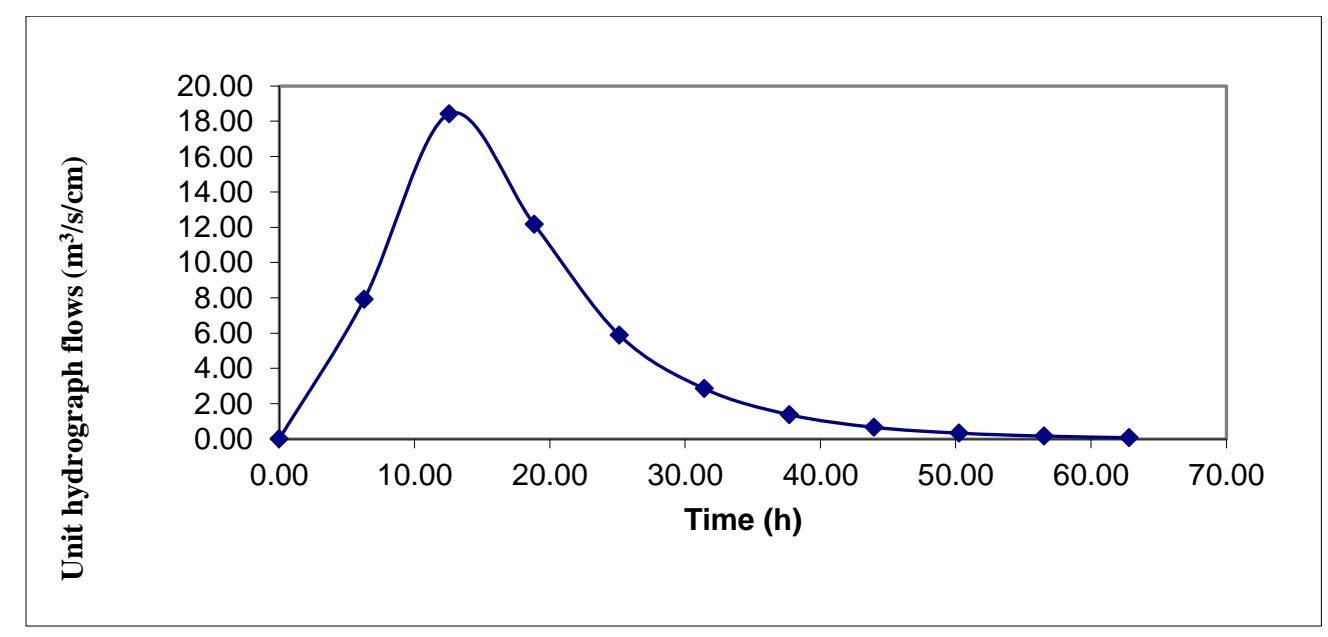

Figure 9. Unit hydrograph flows versus time for sub-catchment 4. 
Equations (5) - (7) were used to estimate the rainfall excess, other parameters used include the rainfall depth for different return period and curve number $(\mathrm{CN})$ was selected based on soil distribution and land use of the study area described in Figures 4 and 5. Tables 8 - 11 presents the results of excess rainfall for different return period. The following are the estimated rainfall excess (R) for 25-years, 24-hr storm was $4.4599 \mathrm{~cm}, 2.3946 \mathrm{~cm}, 0.8815 \mathrm{~cm}$, $0.5881 \mathrm{~cm}$ and $0.4725 \mathrm{~cm}, 50$-years; $24-\mathrm{hr}$ storm was $5.2233 \mathrm{~cm}, 2.6957 \mathrm{~cm}, 0.9872 \mathrm{~cm}, 0.6574 \mathrm{~cm}$ and $0.5276 \mathrm{~cm}, 75 \mathrm{yr}, 24-\mathrm{hr}$ storm was $5.6778 \mathrm{~cm}$, $2.8708 \mathrm{~cm}, 1.0485 \mathrm{~cm}, 0.6977 \mathrm{~cm}$ and $0.5596 \mathrm{~cm}$ and 100 -years, $24-\mathrm{hr}$ storm was $6.0035 \mathrm{~cm}, 2.9946 \mathrm{~cm}$, $1.0919 \mathrm{~cm}, 0.7261 \mathrm{~cm}$ and $0.5821 \mathrm{~cm}$ respectively.

\section{d) Hydrograph Convolution (Runoff hydro-} graph development)

The discrete convolution equation allows the computation of direct runoff $Q_{n}$.

Let $R=$ incremental rainfall excess $(\mathrm{cm})$

$\mathrm{U}=$ unit hydrograph ordinate $\left(\mathrm{m}^{3} / \mathrm{s} / \mathrm{cm}\right)$

The equations of the ordinates are given in the form of the equation below,

Generally:

$Q_{n}=R_{1} U_{n}+R_{2} U_{n-1}+R_{3} U_{n-2}$

The results from peak runoff hydrograph development are summarized in Table 7.

Table 7. Summarized peak runoff values using SCS method.

\begin{tabular}{|c|c|c|c|c|}
\hline \multirow{2}{*}{ Recurrence Interval } & \multicolumn{4}{|c|}{ Peak runoff values $\left(\mathrm{m}^{3} / \mathrm{s}\right)$} \\
\hline & Sub-catchment 1 & Sub-catchment 2 & Sub-catchment 3 & Sub-catchment 4 \\
\hline 25-Year & 117.1 & 105.42 & 124.75 & 105.3 \\
\hline 50-Year & 134.52 & 121.11 & 143.31 & 120.96 \\
\hline 75-Year & 144.79 & 130.35 & 154.25 & 130.2 \\
\hline 100-Year & 152.11 & 136.94 & 162.05 & 136.78 \\
\hline
\end{tabular}

Table 8. Summarized peak runoff values using Cypress Creek method.

\begin{tabular}{|c|c|c|c|c|}
\hline \multirow{2}{*}{ Recurrence Interval } & \multicolumn{4}{|c|}{ Peak runoff values $\left(\mathrm{m}^{3} / \mathrm{s}\right)$} \\
\hline & Sub-catchment 1 & Sub-catchment 2 & Sub-catchment 3 & Sub-catchment 4 \\
\hline 25-Year & 48.03 & 22.80 & 70.72 & 43.86 \\
\hline 50-Year & 53.38 & 25.34 & 78.60 & 48.74 \\
\hline 75-Year & 56.53 & 26.83 & 83.24 & 51.62 \\
\hline 100-Year & 58.78 & 27.90 & 86.55 & 53.68 \\
\hline
\end{tabular}

Table 9. Values of peak runoff using Rational, SCS \& Cypress Creek Formula for sub-catchment 1.

\begin{tabular}{cccc}
\hline & & & $\begin{array}{c}\text { Cypress } \\
\text { Recurrence Interval }\end{array}$ \\
\hline 25-Year & Rational method(m3/s) & SCS method (m3/s) & \\
\hline 50-Year & 548.08 & 117.10 & 48.03 \\
75-Year & 599.90 & 134.52 & 53.38 \\
100-Year & 629.99 & 144.79 & 56.53 \\
& 651.32 & 152.11 & 58.78 \\
\hline
\end{tabular}




\subsubsection{Cypress creek formula}

The nature of flood flows has been found to be dependent on the physiographic and climatological characteristics of the stream drainage basin. This relationship can be expressed by an equation such as the following: (Hydrology Training Series, Module 206D).

$Q=A^{x}+B^{y}+C^{x}+N^{N}$

where,

$Q=$ peak flow for a given return frequency.

A, B, C, and $\mathrm{N}=$ measurable characteristics of the basin, such as size, main channel gradient, land slope, etc.

$\mathrm{x}, \mathrm{y}, \mathrm{z}, \mathrm{n}=$ power functions, obtained by regression analysis.

Studies show that the dominant, and often the only obtainable, basin characteristic of flatland watersheds is size. In this case, the complex general equation may be reduced to the relationship,

$Q=C A^{x}$

The Cypress Creek formula is:

$Q=C M^{5} / 6$

$Q=$ average runoff rate, for the 24-hour period of the greatest runoff for a particular storm event (cfs).

$\mathrm{C}=$ a coefficient, is mainly dependent upon the degree of protection desired.

$\mathrm{M}=$ drainage area, square miles.

\section{i. Development of C}

The value of $C$ varies with runoff, which can be related to rainfall frequency for a 24-hour period, and was computed based on maximum runoff rates. $\mathrm{C}$ reflects frequency, rainfall excess, cover, intensity, etc. For the experimental watersheds, and it is based on the 24-hr average runoff. Next, the coefficient $C$ is evaluated in terms of rainfall excess, and this is related to storm recurrence interval.

$Q=C M^{5} / 6$

Based on numerous runoff events computed by the method of least squares, the regression equation for flatland watersheds is:

$y=16.39+14.75 R_{e}$

$R_{e}=\frac{(P-0.2 S)^{2}}{(P+0.8 S)}$

where,

$y=$ predicted value of the coefficient $C$.

$\mathrm{R}_{\mathrm{e}}=$ rainfall excess for an individual storm, in.

$S=$ volume of total storage (in).

Note: Equation (14) is the same as equation (7).

The value of curve number $(\mathrm{CN})$ used was selected based on soil distribution and land use of the study area as described in Figs. 4 and 5.

$C N=75$

When analyzing the peak runoff for cypress creek method, the following conversion factors were applied:

1 mile $=1.609344 \mathrm{~km} ; 1 \mathrm{~km}=0.6214 \mathrm{mile} ; 1 \mathrm{~km}^{2}=$ $\left(0.6214^{*} 0.6214\right) \mathrm{mi}^{2} ; 1 \mathrm{~km}^{2}=0.3861 \mathrm{mi}^{2} ; 1 \mathrm{in}=$ $25.4 \mathrm{~mm} ; 1 \mathrm{cfs}=0.02831684 \mathrm{~m}^{3} / \mathrm{s}$

\subsection{Graphical Comparison of the Peak Runoff Results Based on the Three Methods}

The results obtained from the three methods used in estimating peak runoff for 25-year, 50year, 75-year and 100-year return period for the sub-catchments within Jere sub-basin are summarized and presented in Tables 9-12 while Figures 10-13 are bar charts, which are plotted to show the graphical representation of the results from the three methods of peak runoff of the different return periods for the subcatchments. 
The comparison is presented graphically as shown in Figs. 10 to 13.

Table 10. Values of peak runoff using Rational, SCS \& Cypress Creek Formula for sub-catchment 2.

\begin{tabular}{cccc}
\hline & & & $\begin{array}{c}\text { Cypress } \\
\text { Recurreek(m) } \mathbf{3} / \mathbf{s})\end{array}$ \\
\hline 25-Year & 224.12 & 105.42 & 22.80 \\
50-Year & 245.31 & 121.11 & 25.34 \\
75-Year & 257.61 & 130.35 & 26.83 \\
100-Year & 266.33 & 136.94 & 27.90 \\
\hline
\end{tabular}

Table 11. Values of peak runoff using Rational, SCS \& Cypress Creek Formula for sub-catchment 3.

\begin{tabular}{|c|c|c|c|}
\hline Recurrence Interval & Rational Method(m³/s) & SCS Method (m³/s) & $\begin{array}{c}\text { Cypress } \\
\text { Creek }\left(\mathrm{m}^{3} / \mathrm{s}\right)\end{array}$ \\
\hline 25-Year & 871.95 & 124.75 & 70.72 \\
\hline 50-Year & 954.40 & 143.31 & 78.60 \\
\hline 75-Year & 1002.46 & 154.25 & 83.24 \\
\hline 100-Year & 1036.19 & 162.05 & 86.55 \\
\hline
\end{tabular}

Table 12. Values of peak runoff using Rational, SCS \& Cypress Creek Formula for sub-catchment 4.

\begin{tabular}{|c|c|c|c|}
\hline Recurrence Interval & Rational Method(m³/s) & SCS Method $\left(\mathrm{m}^{3} / \mathrm{s}\right)$ & $\begin{array}{c}\text { Cypress } \\
\operatorname{Creek}\left(\mathrm{m}^{3} / \mathrm{s}\right)\end{array}$ \\
\hline 25-Year & 491.48 & 105.30 & 43.86 \\
\hline 50-Year & 537.96 & 120.96 & 48.74 \\
\hline 75-Year & 564.94 & 130.20 & 51.62 \\
\hline 100-Year & 584.06 & 136.78 & 53.68 \\
\hline
\end{tabular}

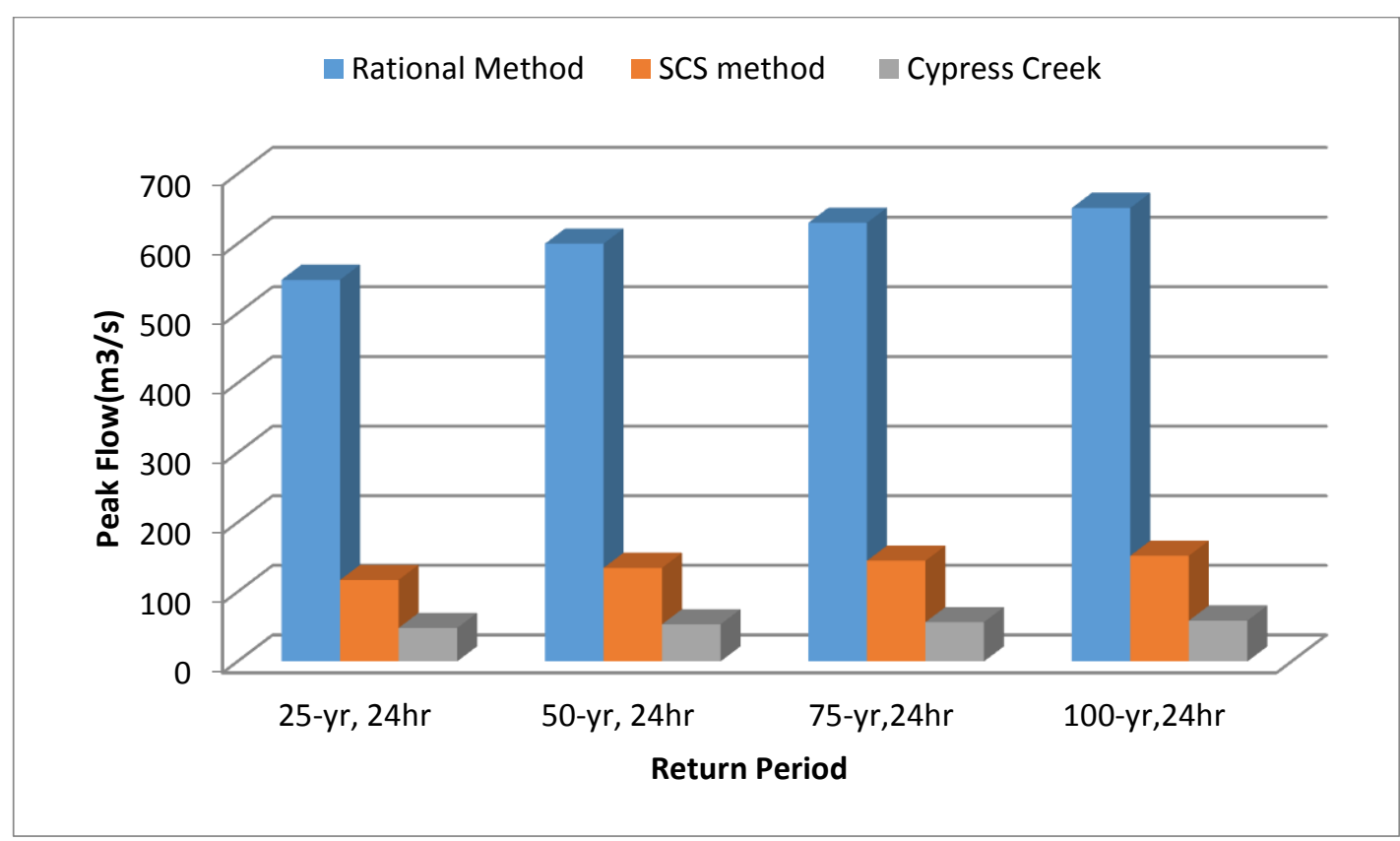

Figure 10. Comparison of Rational, SCS and Cypress Creek methods for sub-catchment 1. 


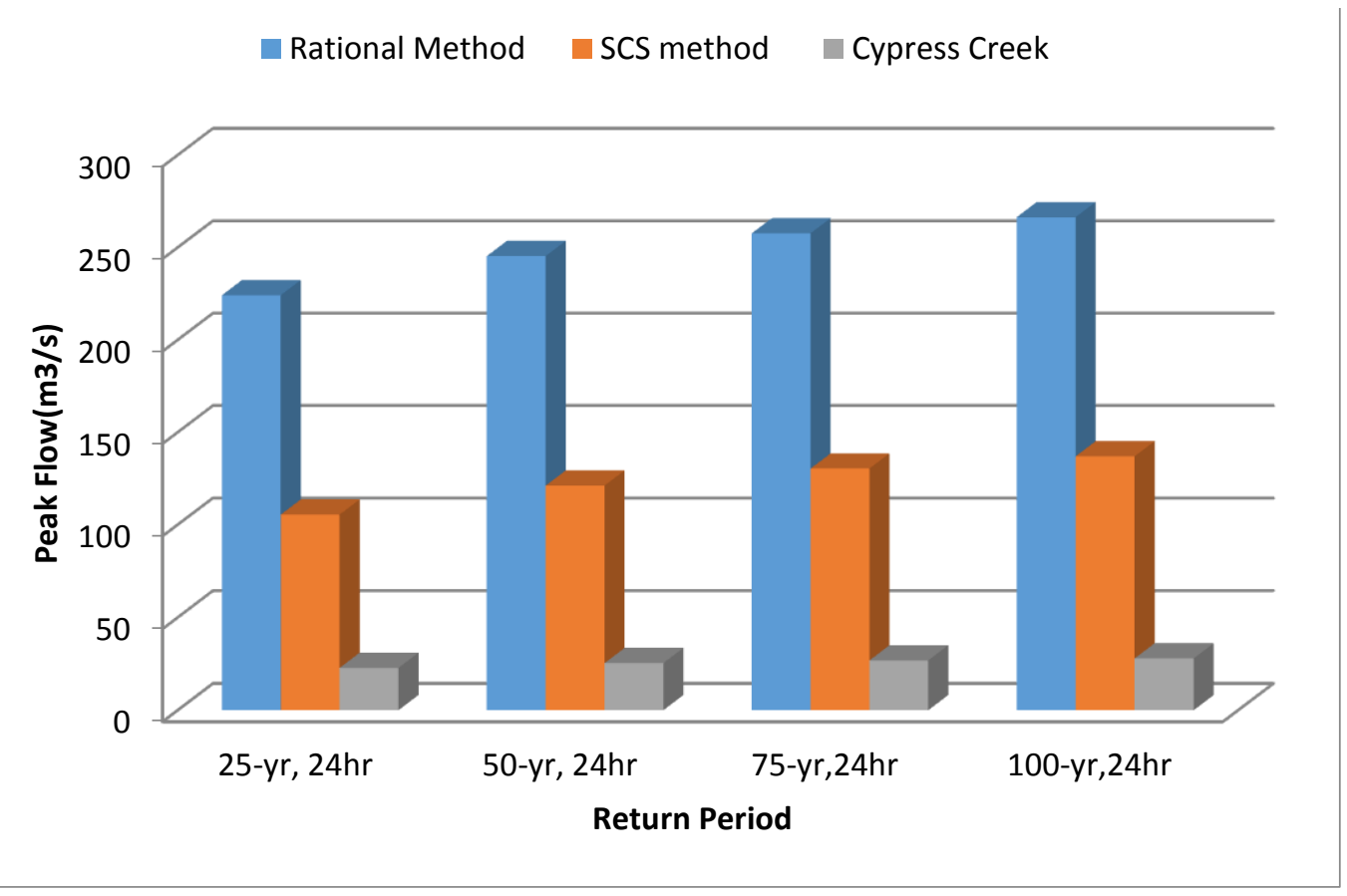

Figure 11. Comparison of Rational, SCS and Cypress Creek methods for sub-catchment 2.

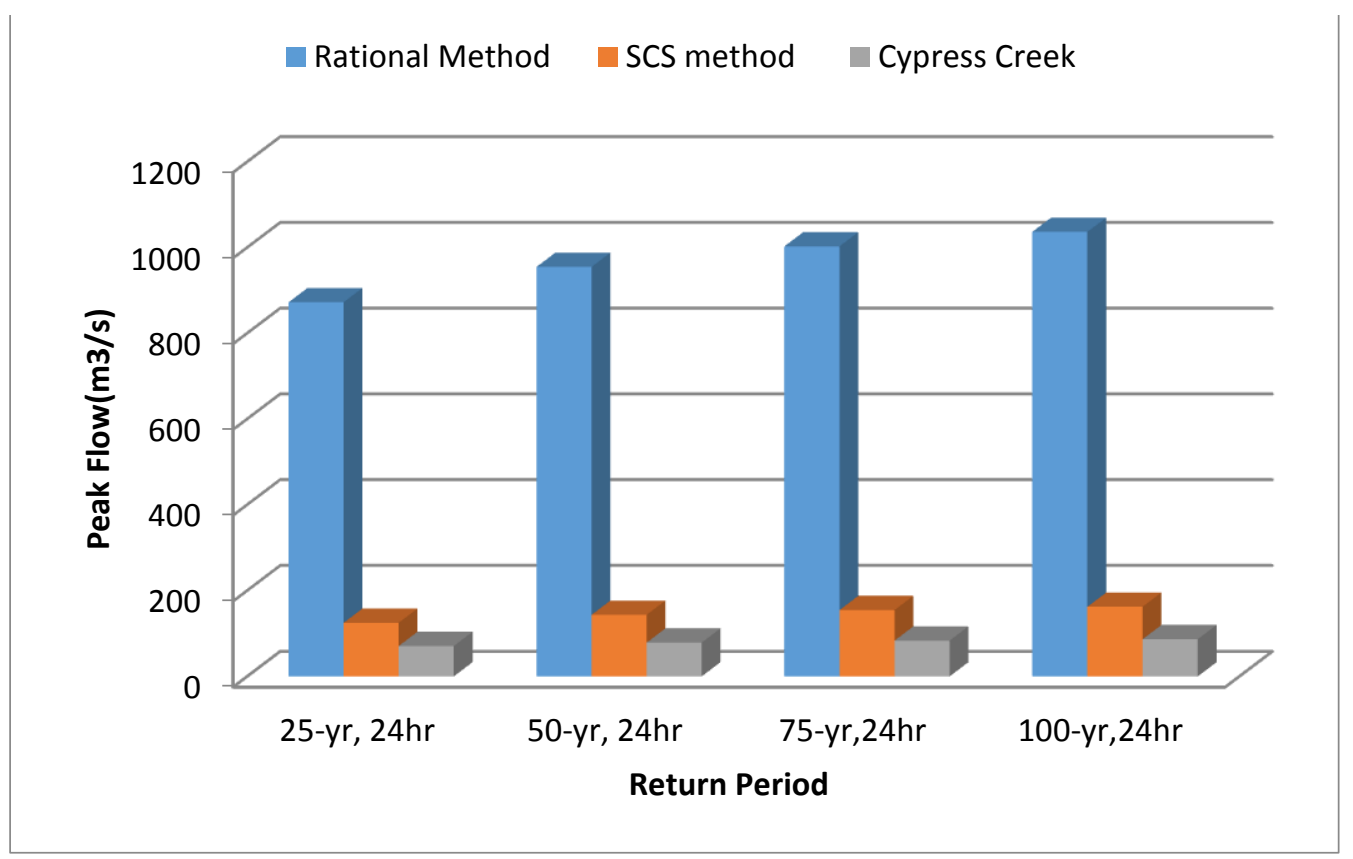

Figure 12. Comparison of Rational, SCS and Cypress Creek methods for sub-catchment 3. 


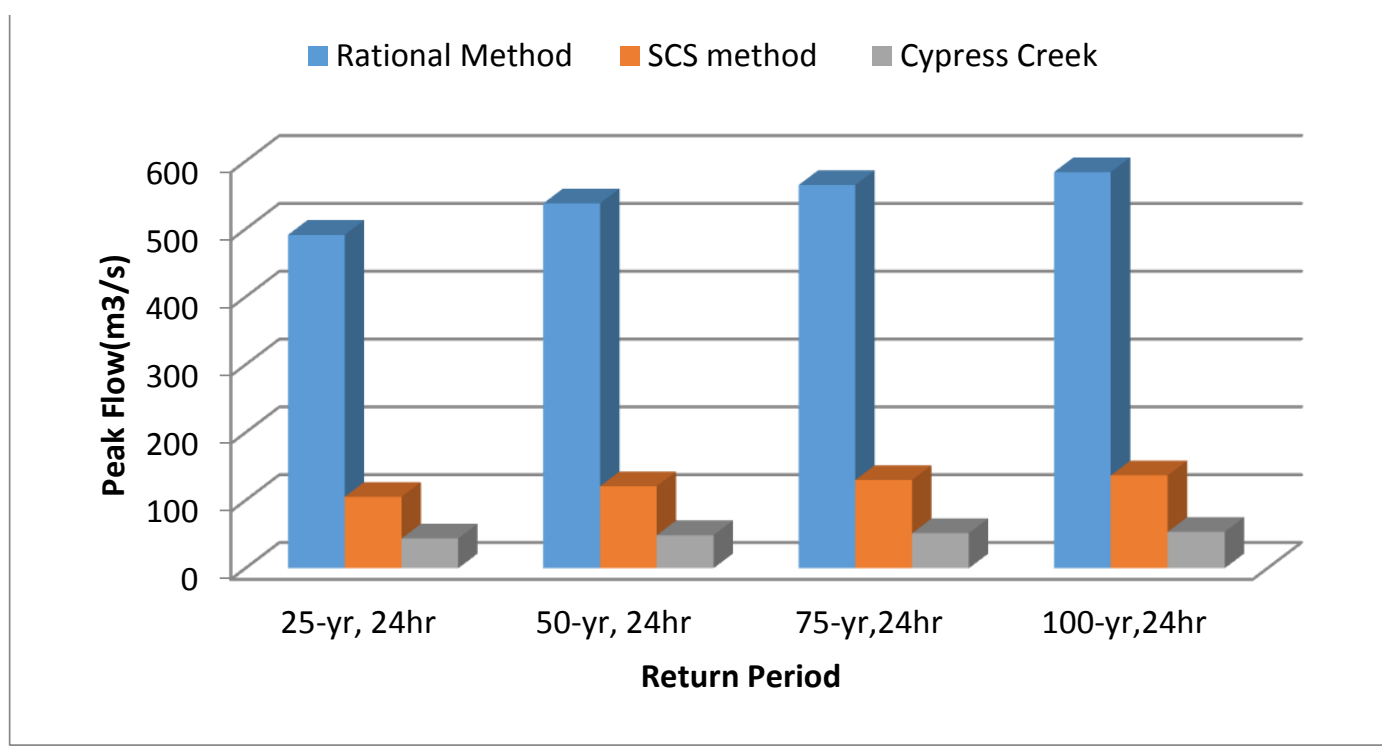

Figure 13. Comparison of Rational, SCS and Cypress Creek methods for sub-catchment 4.

\section{Results and Discussions}

The area considered is a sub-basin within Gurara basin in the North central part of Nigeria with a catchment area of $483 \mathrm{~km}^{2}$ and length of $355 \mathrm{~km}$. Three methods of peak runoff estimation were considered, namely the rational, SCS and Cypress creek methods. From the comparison of peak runoff results obtained from the three methods, it shows that there is a significant difference in the peak runoff results obtained by the three methods. Also, there are significant differences in the peak runoff results obtained for the return periods of 25-years, 50-years, 75-years and 100years. Furthermore, the results show that the positive contribution to the runoff value obtained is based on the values of the morphometric parameters of the basin.

\section{Conclusion}

In this study, physiography and morphometric parameters of catchment area such basin length, basin area, basin slope, soil distribution, land use were analyzed. The parameters were used in estimating/ predicting peak runoff for return periods of 25-years, 50-years, 75-years and 100-years using the rational, SCS and Cypress Creek methods. It can be established that catchment characteristics like area, length, slope etc. have a positive effect on the peak runoff of the sub- basin. The results of the peak runoff obtained showed that the values obtained using the rational method was higher compared to the SCS and Cypress Creek methods for the four sub-catchments. It can therefore be concluded that SCS and Cypress Creek method can be adopted in the estimation of peak runoff in the sub-basin since the values obtained using the two methods are not far apart and are reasonable. Both methods considered the excess rainfall within the sub-catchment and the curve number, which is a function of the properties of the soil and vegetation, cover the sub-catchment in the estimation of peak runoff.

\section{Conflict of Interest}

The authors declare no conflicts of interest.

\section{Funding}

No funding was received for this research.

\section{References}

Carluer N, De M, Ghislain D (2004), Assessment and modeling of the influence of man-made networks on the hydrology of a small watershed-Implications for fast flow components, water quality and landscape management. Journal of Hydrology 285(1): 76-95. 
Donald C, Richard L (2005), Comparison of peak discharge and runoff characteristic estimates from the rational method to field observations for small basins in central Virginia. U.S. Department of the Interior and U.S. Geological Survey.

Ibrahim H, Isiguzo E (2009), Flood frequency analysis of Gurara river catchment at Jere, Kaduna State, Nigeria. Science Research Essay 4(6): 636-646.

McCuen R, Bondelid T (1983), Estimating unit hydrograph peak rate factors. Journal Irrigation Drainage Engineering ASCE 110(7): 887-904.

Miller S (1994), Handbook for Agrohydrology, Natural resources Institute, Overseas Development administration.

Mudashiru R (2015), Hydrologic characterization and peak runoff prediction for Jere sub-basin, Gurara River basin, Nigeria. Master of Engineering Thesis submitted to the School of Postgraduate studies, University of Ilorin, Nigeria.
Ogunlela A, Kasali M (2002), Evaluation of four methods of storm hydrograph development for an ungauged watershed. Nigerian Journal Technology Development 2: 25-34.

Ramirez J (2002), Prediction and modeling of flood hydrology and hydraulics. Chapter 11 of inland flood hazards: Human, Riparian and Aquatic Communities. Edited by Ellen Wohl. Cambridge University Press, USA.

Schwab G, Frevert R, Edminister T, Barnes K (1981), Soil and water conservation engineering. John Wiley and Sons, New York 525.

SCS. Soil Conservation Service (1972), National Engineering Handbook, section 4, Hydrology. US Government Printing Office, Washington DC, 544.

Viessman W, Knapp J, Lewis G (1989), Introduction to hydrology. Harper and Row Publishers. New York 149-355. 